\title{
Protective Human Hybridoma Antibody to Tetanus Toxin
}

\author{
Francis Gigliotti and Richard A. Insel, Department of Pediatrics, Division of \\ Infectious Diseases, University of Rochester, Rochester, New York 14642
}

\begin{abstract}
A B S T R A C T Postimmunization human B lymphocytes and mouse myeloma cells were fused to produce interspecies hybridomas secreting human antibody of predefined specificity with an initial frequency comparable to intraspecies fusion. After 13 mo in culture, one clone continued to secrete high titers of human IgG antitetanus toxin antibody. This antibody binds to the $\mathrm{B}$ fragment of tetanus toxin and protects mice against tetanus. The demonstration of in vivo protection with a human monoclonal antibody is an important first step towards the ultimate goal of human administration of monoclonal antibodies for the prevention and therapy of human infections.
\end{abstract}

\section{INTRODUCTION}

Monoclonal antibodies produced by hybrid cell lines have potential use in the therapy of human infection (1), malignancy (2), and transplantation rejection (3). However, human rather than murine monoclonal antibodies will be required to avoid sensitization to foreign proteins with their in vivo application (4). As yet, protective human monoclonal antibodies have not been described and the optimal method for the production of human hybridoma antibodies is yet to be determined. Only limited success has been reported using human myeloma cell lines as fusion partners to immortalize antibody-producing lymphocytes $(5,6)$. The rapid loss of human chromosomes from mouse myeloma-human lymphocyte hybrid cell lines has hampered the production of human antibody by this technique, although a few interspecies hybrids have been reported (7-9). One possible way to circumvent the instability of interspecies hybrids would be to increase the number of hybrids initially secreting an antibody of predefined specificity, so that more attempts could be made at cloning a stable line. We sought to accomplish this by immunizing volunteers with tetanus toxoid and then harvesting their periph-

Dr. Gigliotti is a Wilmot Cancer Fellow.

Received for publication 30 July 1982 and in revised form 1 September 1982. eral blood B lymphocytes for fusion at a time correlating with peak in vitro production of antitetanus toxoid antibody. Tetanus toxin was chosen as a model antigen because of its potent immunogenicity in man, the availability of a mouse toxin neutralization assay, and because human tetanus immunoglobulin is currently used in both the prevention and therapy of human tetanus.

This report describes production of a stable hybrid cell line that secretes a human IgG antibody by fusing postimmunization human peripheral blood lymphocytes with the nonsecretor mouse myeloma line P3X63-Ag 8.653 (10). This monoclonal antibody (9F12) binds tetanus toxin in vitro and prevents tetanus in vivo in animals. The antigenic specificity of this antibody is described.

\section{METHODS}

Production of human monoclonal antibody. Peripheral blood mononuclear cells were obtained by Ficoll-Hypaque gradient centrifugation of heparinized peripheral blood collected from volunteers 6 or $7 \mathrm{~d}$ after immunization with tetanus and diphtheria toxoids adsorbed (for adult use) (Wyeth Laboratories, Marietta, PA). No volunteer had received a tetanus immunization within the preceding $2 \mathrm{yr}$ and the individual from whom monoclonal antibody $9 \mathrm{~F} 12$ was derived was last immunized $\sim 10$ yr earlier. An enriched B lymphocyte fraction was prepared by incubating the mononuclear cells with 2-aminoethylisothiouronium bromide-treated sheep erythrocytes followed by Ficoll-Hypaque gradient centrifugation to remove lymphocytes rosetting with the erythrocytes (11). The enriched B cells were fused with an equal number of P3-X63-Ag 8.653 mouse myeloma cells, according to a standard fusion protocol (12), using 50\% polyethylene glycol 6000 (Fisher Scientific Co., Fairlawn, NJ) as the fusing agent. After fusion, the cells were maintained in RPMI 1640 media containing $15 \%$ fetal calf serum, $2 \times 10^{-3} \mathrm{M}$ glutamine, $1 \times 10^{-3} \mathrm{M}$ sodium pyruvate, $100 \mathrm{U} / \mathrm{ml}$ penicillin, $100 \mu \mathrm{g} / \mathrm{ml}$ gentamicin, $1 \times 10^{-4}$ hypoxanthine, $1.6 \times 10^{-5} \mathrm{M}$ thymidine (Gibco Laboratories, Grand Island Biological Co., Grand Island, NY), $4 \times 10^{-7} \mathrm{M}$ aminopterin (Sigma Chemical Co., St. Louis, MO), $5 \times 10^{-5}$ M 2-mercaptoethanol (Eastman Kodak Co., Rochester, NY), $5 \mu \mathrm{g} / \mathrm{ml}$ insulin and $5 \mu \mathrm{g} / \mathrm{ml}$ transferrin (Collaborative Research, Lexington, MA). The cells were cultured at a density of $1.5 \times 10^{5}$ cells $/ 0.2 \mathrm{ml}$ in microtiter wells (Costar 3596 , Costar Data Packaging, Cambridge, MA) that contained 
$3 \times 10^{3}$ irradiated mouse peritoneal macrophages as a feeder layer

The hybrid supernatants were screened for antitetanus toxoid antibody production using an enzyme-linked immunosorbent assay (ELISA) ${ }^{1}$ in microtiter plates (Microbiological Associates, Walkersville, MD) preincubated with $100 \mu \mathrm{l}$ of purified tetanus toxoid (Massachusetts Public Health Biologic Laboratories, Boston, MA) at $10 \mu \mathrm{g} / \mathrm{ml}$. Antibody binding to tetanus toxoid was identified with alkaline phosphatase-labeled antisera specific for human immunoglobulin (Ig)G, IgA, and IgM (Atlantic Antibodies, Scarborough, ME) prepared and tested for specificity as has been previously described (13). ELISA assays were also performed with diphtheria toxoid (Massachusetts Public Health Biologic Laboratories), at $1 \mu \mathrm{g} / \mathrm{ml}$.

Antibody-secreting hybrids were passed several times at $d$-10 cells/microtiter well that contained a mouse macrophage feeder layer. After five of these low density passages, hybrid $9 \mathrm{~F} 12$ was cloned twice in a limiting dilution assay at 1 cell/well (14).

Characterization of $9 F 12$. The antibody from the tissue culture supernatant was concentrated $\sim 10$-fold by precipitation with an equal volume of saturated ammonium sulfate (SAS) followed by dialysis against phosphate-buffered saline (PBS). Immunoglobulin heavy and light chain were determined by Ouchterlony immunodiffusion using goat anti-human and anti-mouse antisera (N. L. Cappel Laboratories, Cochranville, PA). The concentration of antibody in tissue culture supernatant allowed to overgrow for several days was determined by radial immunodiff usion using an LC-partigen IgG kit (Calbiochem-Behring Corp., La Jolla, CA).

Determination of the antigenic specificity of $9 F 12$. Purified tetanus toxin was radioiodinated by the lactoperoxidase method using Enzymobeads (15) (Bio-Rad Laboratories, Richmond, CA). The iodinated toxin $(1 \mu \mathrm{Ci} / \mu \mathrm{g})$ was incubated with papain (Boehringer Mannheim Biochemicals, Indianapolis, IN) at a ratio of $2 \mathrm{U}$ papain $/ \mathrm{mg}$ toxin for $3 \mathrm{~h}$ at $55^{\circ} \mathrm{C}$ as previously described (16). SAS concentrated hybridoma supernatant and human serum were then incubated with the papain digest for $1.5 \mathrm{~h}$ at $4^{\circ} \mathrm{C}$ and antigen-antibody complexes were precipitated with formalin-fixed Staphylococcus aureus, strain Cowan 1 (Enzyme Center, Inc., Boston, MA). The precipitate was washed three times with PBS and prepared for SDS-polyacrylamide gel electrophoresis by vortexing the pellet with SDS sample buffer, incubating for 5 min at $20^{\circ} \mathrm{C}$, centrifuging the sample and then boiling the supernatant for 2 min before applying it to a $7.5 \%$ SDSpolyacrylamide gel. The gel was then fixed and autoradiography performed with Kodak X-Omat AR film.

Mouse toxin neutralization assay. The biologic activity of $9 \mathrm{~F} 12$ was investigated using the mouse tetanus toxin neutralization assay (17). Purified tetanus toxin (lot 39, Massachusetts Public Health Biologic Laboratories) in PBS with $0.2 \%$ gelatin (PBS-G) was diluted with an equal volume of either PBS-G, 10-fold SAS concentrated mouse myeloma cell tissue culture supernatant (653), or 10 -fold SAS concentrated human monoclonal antibody $9 \mathrm{~F} 12$ and administered as a 0.5 $\mathrm{ml}$ subcutaneous injection to the right inguinal fold of 1518-g female CD-1 mice (Charles River Laboratories, Wilmington, MA). The minimal lethal dose of this toxin preparation, defined as $100 \%$ death by $96 \mathrm{~h}$, was $0.16 \mathrm{ng}$.

\footnotetext{
${ }^{1}$ Abbreviations used in this paper: ELISA, enzyme-linked immunosorbent assay; SAS, saturated ammonium sulfate.
}

\section{RESULTS AND DISCUSSION}

B lymphocytes prepared for fusion were harvested on days 6 or 7 postimmunization, which in preliminary studies corresponded to the time of peak in vitro antitetanus toxoid antibody production, confirming previously published data (18). In the fusion from which clone $9 \mathrm{~F} 12$ was derived, $6 \times 10^{6}$ B lymphocytes were initially seeded into 80 microtiter wells. Hybrids were observed in 28 of the 80 wells by 3 wk after fusion. 5 of the 28 wells contained human antitetanus toxoid antibody, all of the IgG isotype. Four of the five wells were passed at 10 cells/well and reassayed for continued antibody production. After several cycles of this procedure, one clone, $9 \mathrm{~F} 12$, continued to produce high titers of antibody of the IgG class with $k$ light chain (Fig. 1). No mouse immunoglobulin was detectable. Karyotyping performed after the second cloning by limiting dilution assay showed the cells to have a modal chromosomal number of 108 with $\sim 101$ mouse and 6-7 intact human chromosomes. Antibody production measured $4 \mathrm{mo}$ after fusion was $\sim 2.5 \mu \mathrm{g} / \mathrm{ml}$. Repeat determination 4 mo later and after successful cloning showed antibody production to be slightly increased at $5-10 \mu \mathrm{g} / \mathrm{ml}$.

Following the same protocol, B lymphocytes from three other immunized volunteers were fused and seeded into a total of 384 wells. Viable hybrids grew in 94 of the wells and 5 of these secreted human antitetanus toxoid antibody of the IgG isotype. Low den-

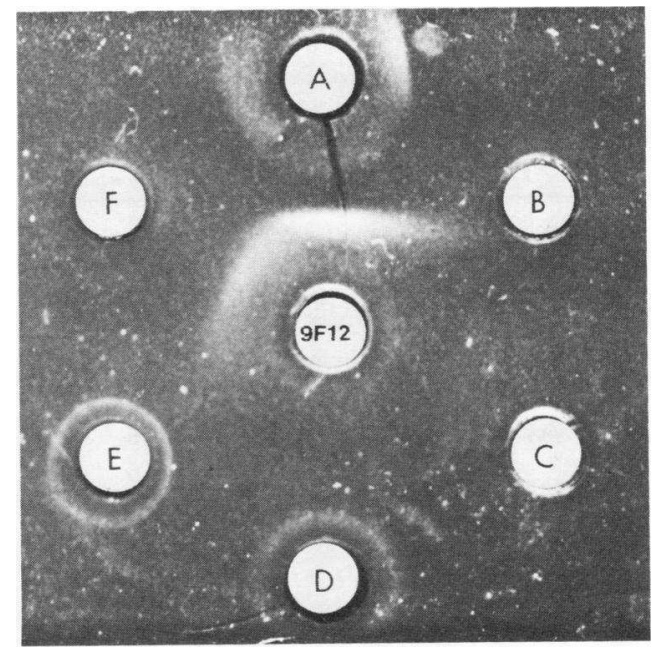

Figure 1 Ouchterlony immunodiffusion pattern of human monoclonal antibody to tetanus toxin (9F12). The outer wells contain the following goat antisera: anti-human $\operatorname{IgG}(\mathrm{A})$, antihuman $\operatorname{Ig} \mathrm{A}(\mathrm{B})$, anti-human $\operatorname{IgM}(\mathrm{C})$; anti-mouse $\operatorname{IgM}, \operatorname{IgG}$, and $\operatorname{Ig} A(D)$, anti-human $\lambda$-light chain (E) and anti-human k light chain $(F)$. 
sity passage was attempted on three of the secreting hybrids but we were unable to maintain antibody production for $>1$ mo. Human antidiphtheria toxoid antibody was detected in supernatants of 3 of the 122 hybrids. No supernatants reacted with both tetanus and diphtheria toxoids.

We were able to demonstrate the protective capacity of this human hybridoma antibody using the mouse tetanus toxin neutralization assay. Data from a representative experiment are shown in Table I. All 15 animals that received tetanus toxin neutralized by preincubation with antibody $9 \mathrm{~F} 12$ were completely protected. On the other hand, all 34 animals that received toxin preincubated with PBS-G, or the parent mouse myeloma cell culture supernatant, were either killed or paralyzed by the toxin. These results were reproducible in four replicate determinations. To the best of our knowledge, this is the first demonstration of toxin neutralization by a hybridoma antibody. The possibility does exist that there could be a mutant tetanus toxin which would not be neutralized by monoclonal antibody 9F12. However, mutant forms of tetanus toxin have never been described.

Tetanus toxin has a molecular weight of $\sim 150,000$ and consists of two polypeptide chains linked by a disulfide bond. With reduction, the extracellular form of the toxin is split into its constituent heavy and light chains. Papain digestion cleaves the molecule into a 47,000 -mol wt fragment $C$ and an $\sim 95,000-\mathrm{mol}$ wt fragment B (16). Fragment C consists of the carboxy terminal half of the heavy chain and is responsible for

TABLE I

Mouse Tetanus Toxin Neutralization Assay Using Human Monoclonal Antibody as Antitoxin

\begin{tabular}{|c|c|c|c|c|c|c|}
\hline \multicolumn{7}{|c|}{ No. dead/No. total at indicated time after toxin administration } \\
\hline \multirow[b]{2}{*}{ Toxin dose } & \multicolumn{6}{|c|}{$h$} \\
\hline & 24 & 48 & 72 & 96 & 120 & 144 \\
\hline $0.16 \mathrm{ng}$ in $\mathrm{PBS}-\mathrm{G}^{\circ}$ & $0 / 9$ & $0 / 9$ & $8 / 9$ & $9 / 9$ & - & - \\
\hline $0.16 \mathrm{ng}$ in $653^{\circ}$ & $0 / 5$ & $0 / 5$ & $4 / 5$ & $5 / 5$ & - & - \\
\hline $0.16 \mathrm{ng}$ in $9 \mathrm{~F} 12 \ddagger$ & $0 / 5$ & $0 / 5$ & $0 / 5$ & $0 / 5$ & $0 / 5$ & $0 / 5$ \\
\hline $0.08 \mathrm{ng}$ in PBS-G & $0 / 5$ & $0 / 5$ & $0 / 5$ & $1 / 5$ & $4 / 5$ & $5 / 5$ \\
\hline $0.08 \mathrm{ng}$ in 653 & $0 / 5$ & $0 / 5$ & $0 / 5$ & $2 / 5$ & $4 / 5$ & $5 / 5$ \\
\hline $0.08 \mathrm{ng}$ in $9 \mathrm{~F} 12$ & $0 / 5$ & $0 / 5$ & $0 / 5$ & $0 / 5$ & $0 / 5$ & $0 / 5$ \\
\hline $0.04 \mathrm{ng}$ in PBS-G & $0 / 5$ & $0 / 5$ & $0 / 5$ & $0 / 5$ & $0 / 5$ & $0 / 5$ \\
\hline $0.04 \mathrm{ng}$ in 653 & $0 / 5$ & $0 / 5$ & $0 / 5$ & $0 / 5$ & $0 / 5$ & $0 / 5$ \\
\hline $0.04 \mathrm{ng}$ in $9 \mathrm{~F} 12$ & $0 / 5$ & $0 / 5$ & $0 / 5$ & $0 / 5$ & $0 / 5$ & $0 / 5$ \\
\hline
\end{tabular}

- All animals receiving 0.16 or $0.08 \mathrm{ng}$ of toxin in PBS-G or 653 died by $6 \mathrm{~d}$, while those receiving $0.04 \mathrm{ng}$ survived but had rightsided paralysis.

$\ddagger$ All three groups receiving $9 \mathrm{~F} 12$ showed no clinical signs of tetanus.

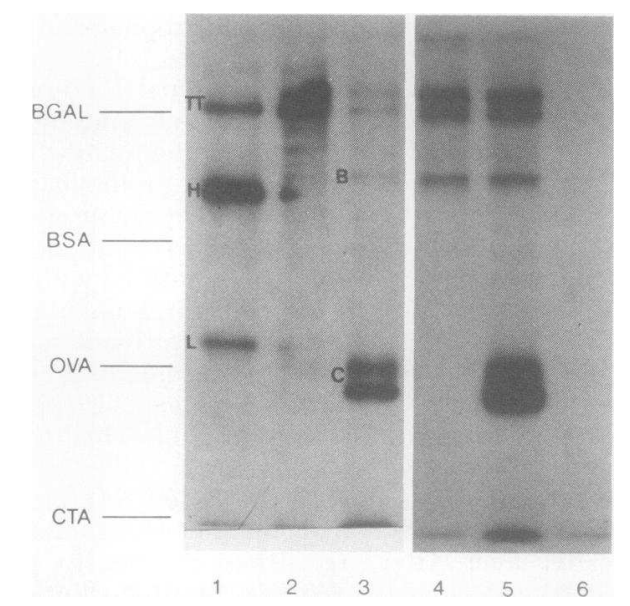

Figure 2 SDS-polyacrylamide gel electrophoresis of papain digested ${ }^{125}$ I-labeled tetanus toxin (TT) after incubation with 9F12 or heterologous antisera (FG) and precipitation with S. aureus, strain Cowan 1. TT was reduced by boiling the sample in $5 \%$ 2-mercaptoethanol for $2 \mathrm{~min}$ before loading the sample on the gel. Lanes contain the following: 1-reduced TT, 2-nonreduced TT, 3-TT digested with papain, 4TT digested with papain and incubated with 9F12, 5-TT digested with papain and incubated with FG, 6-TT digested with papain and incubated with fetal calf serum. $H$, heavy chain, L, light chain, B, fragment B, C, fragment C. TT and fragment $C$ may appear as a doublet or triplet in SDS-polyacrylamide gels. The tetanus toxin has not been completely digested with papain. Molecular weight markers were $\beta$-galactosidase (BGAL), bovine serum albumin (BSA), ovalbumin (OVA) and chymotrypsinogen A (CTA).

the binding of the toxin to its in vivo receptor (19). Fragment $B$ consists of the remaining portion of the heavy chain linked to the entire light chain. Although the function of fragment $B$ is unknown, it is hypothesized to contain the toxin principle of the molecule (20).

Hybridoma antibody $9 \mathrm{~F} 12$ binds both intact tetanus toxin and toxin fragment B (Fig. 2). Serum (FG) from the individual whose lymphocytes were used in the fusion producing 9F12 bound both fragments B and $\mathrm{C}$ as well as the intact toxin. Other experiments (data not shown) demonstrated that $9 \mathrm{~F} 12$, in contrast to the FG serum, is unable to bind purified toxin heavy or light chains that were obtained by treatment of tetanus toxin with dithiothreitol and urea and isolation of the chains by gel filtration as described (21). This would suggest that the antigenic specificity of $9 \mathrm{~F} 12$ is directed to either a conformational epitope requiring the disulfide linkage of the heavy and light chain or an epitope on one of the chains that was denatured with reduction and dissociation of the toxin. The actual mechanism of toxin neutralization by the monoclonal antibody is under investigation. 
The advent of monoclonal antibody technology has rekindled an interest in the passive immunotherapy of various human diseases. However, up to this point, most monoclonal antibodies have been of mouse origin and protective human monoclonal antibodies have not been reported. This report demonstrates that it is possible to produce monoclonal antibodies of human origin with a specifically desired biologic function using readily accessible human lymphocytes. Specific antibody secretion occurred in $11 \%(13 / 122)$ of the mousehuman hybrids using postimmunization human lymphocytes, which is comparable to results obtained with intraspecies fusions. Recently, other investigators have also been successful in producing mouse-human $\mathrm{fu}_{\mathrm{u}}$ sions after in vivo immunization (9). The protective capacity of $9 \mathrm{~F} 12$ against tetanus demonstrates that a monoclonal antibody can neutralize this toxin and supports the prospect that human monoclonal antibody will have a role in the prevention and treatment of human infection.

\section{ACK NOWLEDGMENTS}

We thank Ann Kittelberger for technical assistance and Larry Wisniewski for karyotyping the hybrid cell line.

This work was supported in part by National Institutes of Health grant AI 17217 and by U. S. Public Health Service grant RR 05403-BRSG

\section{REFERENCES}

1. Gigliotti, F., and R. A. Insel. 1982. Protection from Haemophilus influenzae type B infection with anticapsular monoclonal antibody. J. Infect. Dis. 146: 249-254.

2. Ritz, J., J. M. Pesando, S. E. Sallan, I. A. Clavell, and J. Notis-McConarty. 1981. Serotherapy of acute lymphoblastic leukemia with monoclonal antibody. Blood. 58: $141-152$.

3. Cosimi, A. B., R. B. Colvin, R. C. Burton, R. H. Rubin, G. Goldstein, P. C. Kung, W. P. Hansen, F. L. Delmonico, and P. S. Russell. 1981. Use of monoclonal antibodies to $\mathrm{T}$-cell subsets for immunologic monitoring and treatment in recipients of renal allografts. N. Engl. J. Med. 305: 308-314.

4. Sears, H. F., B. Atkinson, J. Mattis, C. Ernst, D. Herlyn, Z. Steplewski, P. Hayry, and H. Koprowski. 1982. Phase 1. Clinical trial of monoclonal antibody in treatment of gastrointestinal tumors. Lancet. I: 762-765.

5. Croce, C. M., A. Linnenbach, W. Hall, Z. Steplewski, and H. Koprowski. 1980. Production of human hybridomas secreting antibodies to measles virus. Nature (Lond.). 288: 488-489.

6. Olsson, L. and H. S. Kaplan. 1980. Human-human hybridomas producing monoclonal antibodies of prede- fined antigenic specificity. Proc. Natl. Acad. Sci. USA 77: 5429-5431

7. Schlom, J., D. Wunderlich, and Y. A. Teramoto. 1980. Generation of human monoclonal antibodies reactive with human mammary carcinoma cells. Proc. Natl. Acad. Sci. USA. 77: 6841-6845.

8. Nowinski, R., C. Berglund, J. Lane, M. Lostrom, I. Bernstein, W. Young, and S. Hakomori. 1980. Human monoclonal antibody against Forssman antigen. Science (Wash. DC). 210: 537-539.

9. Lane, H. C., J. H. Shelhamer, H. S. Mostowski, and A. S. Fauci. 1982. Human monoclonal anti-keyhole limpet hemocyanin antibody-secreting hybridoma produced from peripheral blood B lymphocvtes of a keyhold limpet hemocyanin-immune individual. J. Exp. Med. 155: $333-337$.

10. Kearney, J. F., A. Radbruch, B. Liesegang, and K. Rajewsky. 1979. A new mouse myeloma line that has lost immunoglobulin expression that permits the construction of antibody-secreting hybrid cell lines. J. Immunol. 123: $1548-1550$.

11. Saxon, A., J. Feldhaus, and R. A. Robins. 1976. Single step separation of human $T$ and $B$ cells using AET treated SRBC rosettes. J. Immunol. Methods. 12: 285288.

12. De St. Groth, S. F., and D. Scheidegger. 1980. Production of monoclonal antibodies, strategy and tactics. $J$. Immunol. Methods. 35: 1-21.

13. Insel, R. A., P. Anderson, M. R. Loeb, and D. H. Smith. 1981. A polysaccharide-protein complex from Haemophilus influenzae type b. II. Human antibodies to its somatic components. J. Infect. Dis. 144: 521.

14. Goding, J. W. 1980. Antibody production by hybridomas. J. Immunol. Methods. 39: 285-308.

15. Marchalonis, J. J. 1969. An enzymatic method for the trace iodination of immunoglobulins and other proteins. Biochem. J. 113: 299-305.

16. Helting, T. B., and O. Zwisler. 1977. Structure of tetanus toxin. 1. Breakdown of the toxin molecule and discrimination between polypeptide fragments. J. Biol. Chem. 252: $187-193$.

17. Barile, M. F., M. C. Hardegree, and M. Pittman, 1970. Immunization against neonatal tetanus in New Guinea. 3. The toxin neutralization test and the response of guinea pigs to the toxoids as used in the immunization schedules in New Guinea. Bull. WHO 43: 453-458.

18. Stevens, R., E. Macy, C. Morrow, and A. Saxon. 1979. Characterization of a circulating subpopulation of spontaneous anti-tetanus toxoid antibody producing cells following in-vivo booster immunization. J. Immunol. 122: 2498-2504.

19. Helting, T. B., and O. Zwisler. 1977. Structure of tetanus toxin. II. Toxin binding to gangliosides. J. Biol. Chem. 252: $194-198$.

20. Bizzini, B. 1979. Tetanus toxin. Microbiol. Rev. 43: 224240.

21. Matsuda, M., and M. Yoneda. 1975. Isolation and purification of two antigenically active, "complementary" polypeptide fragments of tetanus neurotoxin. Infect. Immun. 12: 1147-1153. 